\title{
EFFECTS OF FEEDING LOW PROTEIN DIETS ON SERUM AND FAECES PARAMETERS IN WEANED PIGLETS
}

\author{
Bindas, L., Bujňák, L., Maskalová, I. \\ Mihok, T., Timkovičová Lacková, P., Nad', P. \\ Department of Nutrition, Dietetics and Animal Breeding \\ Institute of nutrition, dietetics and feed production \\ University of Veterinary Medicine and Pharmacy in Košice, \\ Komenského 73, 04181 Košice \\ Slovakia
}

lubor.bindas@uvlf.sk

\section{ABSTRACT}

This study was conducted to determine the effects of a low-protein diet supplemented with synthetic amino acids on the biochemical parameters in the blood serum, the indicators of fermentation processes, and nitrogen excretion in 12 crossbred piglets. The piglets (weaned at 28 days of age) were divided into two groups with 6 piglets each. The control group had an initial average body weight of $8.8 \pm 0.6 \mathrm{~kg}$ and the experimental group with an average initial body weight of $8.6 \pm 0.7 \mathrm{~kg}$. The control diet contained $210.8 \mathrm{~g} . \mathrm{kg}^{-1}$ crude protein and the experimental diet contained $186.4 \mathrm{~g} . \mathrm{kg}^{-1}$. The experimental diet was supplemented with lysine, methionine and threonine to achieve a more ideal amino acid pattern. The blood collections from the sinus ophthalmicus for the determination of the biochemical parameters were performed 4 times at weekly intervals in the control and experimental groups $4-5$ hours after feeding. The faeces were taken from the rectum at the end of the study period. The decrease in the dietary crude protein content of the experimental group was manifested by a significant decrease of the blood urea level $\left(2.61 \mathrm{mmol}^{-1}\right.$ average concentration) compared to the control groups (4.21 $\mathrm{mmol} . \mathrm{l}^{-1}$ average concentration) $(\mathrm{P}<0.001)$. The other serum component concentrations (total protein, albumin, glucose, cholesterol, total lipids and selected enzymes) showed no significant statistical changes between the control and experimental groups. The results of the fermentation process analysis indicated that the butyrate concentration decreased $(P=0.0017)$ and the pH increased $(\mathrm{P}=\mathbf{0 . 0 1 8 0})$ in the experimental group compared to the control group. The levels of crude protein and ammonia in the faeces of experimental animals were significantly lower $(\mathrm{P}<\mathbf{0 . 0 0 1})$ in comparison with those in the control animals.

Key words: amino acids; ammonia; crude protein; fermentation; metabolism; pig, volatile fatty acids 


\section{INTRODUCTION}

Because of the increased availability of crystalline amino acids (AA) (lysine, methionine, and threonine, including the "new" amino acids isoleucine and valine), and the continual need to improve the utilization of nutrients to reduce the impact of livestock production on the environment, there is always a need to more fully understand amino acid nutrition of non-ruminants [13]. Lysine is the first limiting amino acid in a typical swine diet and it plays a very important role in promoting the growth performance of pigs [25]. Dietary supplementation of crystalline lysine for pigs can significantly increase body muscle protein accretion, which may be due to a greater increase in the rate of protein biosynthesis rather than that of protein degradation [11, 17]. In addition, nutritional studies have demonstrated that dietary supplementation with several AA: modulates gene expression, enhances growth of the small intestine and skeletal muscle, or reduces excessive body fat $[6,8,26,37]$.

A reduction of dietary crude protein (CP) could limit the growth performance of growing pigs, but a low-protein diet, supplemented with deficient amino acids, could reduce the excretion of nitrogen into the environment without affecting weight gain $[2,10,36]$. The dietary CP concentration can be decreased from 15 to $12 \%$ with crystalline amino acid supplementation to meet an ideal amino acid profile without adversely affecting the nitrogen retention [23]. Supplements of synthetic amino acids to animal diets are important not only on nutritional and economic aspects, but also on the environmental aspects [9]. It is concluded that the supplementation of limited amounts of synthetic amino acids to diets for swine could spare 2 to 3 percentage units of dietary protein and substantially reduce the nutrient excretion, especially of nitrogen [9]. The metaanalysis of Sajeev et al. [28] confirmed that CP in animal diets and the emissions of ammonia demonstrated a clear relationship. The meta-analysis revealed a mean ammonia reduction of $17 \pm 6 \%$ per $\%$-point $\mathrm{CP}$ for cattle and $11 \pm 6 \%$ for pigs. Most studies indicated that the reduction of dietary CP could effectively decrease the nitrogen emission $[11,30,31]$. This fact motivated us to determine the effects of reducing the dietary CP content from 21.1 to $18.6 \%$ on serum biochemical parameters and indicators of fermentation processes.

\section{MATERIALS AND METHODS}

\section{Animals and diets}

This study was conducted on 12 crossbred piglets (Slovakian WhitexLandrace), with an initial average body weight (BW) of $8.8 \pm 0.6$ in the control and $8.6 \pm 0.7 \mathrm{~kg}$ in the experimental group with weaning at 28 days of age in both groups. At weaning, piglets were divided into two groups ( 6 pigs in each group). Both groups contained equal numbers of females (2) and castrated males (4). The experimental period lasted 28 days.

The same basic ingredients for the control and experimental groups were used in the study. The diets were formulated based on corn, wheat, barley, soybean meal, vitamin + mineral premix, and salt. The animals were divided into two groups according to the two different $\mathrm{CP}$ levels of diet $(21.1 \%$ and $18.6 \%$; the reduction of CP by $2.5 \%$ in the experimental group) with different soybean meal concentration in diets (29 vs. $23 \%$ ). The addition of limiting amino acids (lysine, methionine, and threonine) was used in the experimental diet. All piglets were fed a diet formulated according to the National Research Council recommendations [21] for limiting amino acids. Feed and water were allowed on an ad libitum basis. The feed composition of the diets used in the study and their nutrient content are shown in Table 1 and 2.

The investigation was carried out in the animal quarters of the Institute of Animal Nutrition and Dietetics at the University of Veterinary Medicine and Pharmacy in Košice in compliance with the EU regulations concerning the welfare of experimental animals.

\section{Analysis}

The diets were analysed for their dry mater (DM), crude protein (CP), crude fibre (CF), acid detergent fibre (ADF), neutral detergent fibre (NDF), ether extract (EE) and ash by the AOAC [1]. The nitrogen free extract (NFE) was mathematically calculated from previous parameters. The amino acids content in both diets were calculated according to the program for formulation of diets for pigs from AA composition of feeds and the addition of synthetic amino acids.

The blood collection from the sinus ophthalmicus for the determination of the biochemical parameters was performed 4 times at weekly intervals in the control and experimental group 4-5 hours after feeding. The biochemical parameters of the blood serum (total proteins, albumin, 
Table 1. Ingredients (\%) of diets used in the experiment

\begin{tabular}{lcc}
\hline \multicolumn{1}{c}{ Ingredients } & Control diet & Experimental diet \\
\hline Corn & 26 & 28 \\
Wheat & 26.8 & 28 \\
Barley & 15 & 17.4 \\
Soybean meal, CP 48 \% & 29 & 23 \\
Mineral-vitamin premix & 3 & 3 \\
Salt & 0.2 & 0.2 \\
L-Lysine HCl 78 \% & & 0.22 \\
DL-Methionine & & 0.08 \\
L-Threonine 98\% & & 0.1 \\
\hline
\end{tabular}

$\mathrm{CP}$-crude protein

Table 2. Chemical composition (g.kg-1, as fed basis, as dry matter basis) of diets containing different levels of crude protein for piglets

\begin{tabular}{|c|c|c|c|c|}
\hline \multirow{2}{*}{$\begin{array}{c}\begin{array}{c}\text { Parameters } \\
{\left[\mathrm{g} \cdot \mathrm{kg}^{-1}\right]}\end{array} \\
\mathrm{DM}\end{array}$} & \multicolumn{2}{|c|}{$\begin{array}{c}\text { Control } \\
\text { diet }\end{array}$} & \multicolumn{2}{|c|}{$\begin{array}{l}\text { Experimental } \\
\text { diet }\end{array}$} \\
\hline & 903.70 & 1000 & 902.70 & 1000 \\
\hline $\mathrm{CP}$ & 210.80 & 233.26 & 186.40 & 206.49 \\
\hline EE & 13.30 & 14.72 & 12.90 & 14.29 \\
\hline $\mathrm{CF}$ & 38.60 & 42.71 & 39.50 & 43.76 \\
\hline NDF & 161.00 & 178.16 & 169.9 & 188.21 \\
\hline ADF & 49.80 & 55.11 & 47.50 & 52.62 \\
\hline Ash & 67.80 & 75.02 & 65.40 & 72.45 \\
\hline NFE & 573.20 & 634.29 & 598.50 & 633.01 \\
\hline Lys & 12.60 & 13.94 & 13.00 & 14.40 \\
\hline Thr & 7.90 & 8.73 & 8.00 & 8.86 \\
\hline Met+Cys & 6.70 & 7.41 & 6.90 & 7.64 \\
\hline
\end{tabular}

$\mathrm{CP}$-crude protein; $\mathrm{EE}$ - etheric extract; $\mathrm{CF}$-crude fibre; NDF- neutral-detergent fibre; $\mathrm{ADF}$-acid-detergent fibre NFE-nitrogen-free extract; Lys-lysine; Thr-threonine; Met+Cys-methionine + cysteine

urea, glucose, total lipids, cholesterol, AST aspartate aminotransferase, and AP alkaline phosphatase) were determined using a fully automatic random access benchtop analyser Ellipse (Italy).

The faeces were taken directly from the rectum at the end of the investigation. The quantitative determination of the volatile fatty acids (VFA) was done by the method of isotachophoresis employing a two-capillary analyser EA100 (VILLA LABECO, Slovakia). The samples of faeces were analysed for $\mathrm{pH}$ ( $\mathrm{pH}$ meter Consort C830, Belgium) from extract (4hours $/ 2 \mathrm{~g}$ fresh faeces plus $20 \mathrm{ml}$ distilled water). The dry matter, $\mathrm{CP}$ and ammonia $\left(\mathrm{NH}_{3}\right)$ in the faeces were determined according to the AOAC [1]. 


\section{Statistical methods}

All data were reported as the mean \pm SD (standard deviation). The differences between means were determined according to the unpaired t-test using Graph-Pad Prism statistical program (Graph Prism software, USA). By conventional criteria, differences $(\mathrm{P}<0.05 ; \mathrm{P}<0.01 ; \mathrm{P}<0.001)$ were considered to be statistically significant.

\section{RESULTS}

The first part of our study was performed to investigate the effects on the biochemical parameters in the blood serum following the feeding of a low crude protein diet to piglets. The metabolic variables in the blood serum are shown in Table 3.

No significant differences were seen between the control and experimental groups in the serum metabolites related to protein metabolism; total protein and albumin. The average concentrations of total protein and albumin for all four weeks of the study period were slightly higher in the con- trol group (53.85 g. $1^{-1}$ and 32.80 g. . $^{-1}$, respectively) compared to the experimental group (51.85 g. $\mathrm{l}^{-1}$ and $31.35 \mathrm{~g} . \mathrm{l}^{-1}$, respectively). The urea as an important indicator of protein nutrition showed marked changes. Throughout the study, the serum urea concentration was significantly lower $(\mathrm{P}<0.001)$ in pigs fed the experimental diet, with the low CP diet supplemented with essential amino acids (Lys, Met, Thr), compared to the control diet which contained higher CP.

No significant differences between groups in other serum parameters of energy metabolism and enzyme activity were found. The mean values of energy metabolism parameters during the whole investigative period varied in the control vs. experimental group in glucose (4.99 vs. $5.02 \mathrm{mmol}^{-1} \mathrm{l}^{-1}$, total lipids (1.74 vs. $\left.1.70 \mathrm{~g} . \mathrm{l}^{-1}\right)$, cholesterol (2.06 vs. $1.94 \mathrm{mmol}^{-1}$ ), respectively. The CP level in the diet did not affect the enzyme activity related to tissues damages (ALT) and biochemical plasma marker of bone mineral turnover (AP), although a tendency of lower activity of these enzymes in the control group compared to the experimental group was recorded; AST (0.28 vs. $\left.0.31 \mu \mathrm{kat}^{-1} \mathrm{l}^{-1}\right)$ and $\operatorname{AP}\left(5.14\right.$ vs. $5.83 \mu$ kat. $\left.^{-1}\right)$, respectively. The biochemi-

Table 3. Effects of different dietary CP content on biochemical parameters of piglets

\begin{tabular}{|c|c|c|c|c|c|c|c|c|c|c|}
\hline \multirow{2}{*}{$\begin{array}{c}\text { Parameters } \\
\text { Week }\end{array}$} & \multicolumn{5}{|c|}{ Control group } & \multicolumn{5}{|c|}{ Experimental group } \\
\hline & 1 & 2 & 3 & 4 & $1-4$ & 1 & 2 & 3 & 4 & $1-4$ \\
\hline Total protein & 51.90 & 52.94 & 55.86 & 54.70 & 53.85 & 50.74 & 53.74 & 53.30 & 49.61 & 51.85 \\
\hline$\left[\mathrm{g} .1^{-1}\right]$ & \pm 2.85 & \pm 2.96 & \pm 3.40 & \pm 3.27 & \pm 3.12 & \pm 1.89 & \pm 2.69 & \pm 3.82 & \pm 1.33 & \pm 2.43 \\
\hline Urea & $2.92^{\mathrm{a}}$ & $4.52^{\mathrm{a}}$ & $4.39^{\mathrm{a}}$ & $4.99^{\mathrm{a}}$ & $4.21^{\mathrm{a}}$ & $1.69^{\mathrm{b}}$ & $3.06^{\mathrm{b}}$ & $2.63^{b}$ & $3.06^{\mathrm{b}}$ & $2.61^{\mathrm{b}}$ \\
\hline$\left[\mathrm{mmol} . \mathrm{1}^{-1}\right]$ & \pm 0.11 & \pm 0.48 & \pm 0.32 & \pm 0.51 & \pm 0.35 & \pm 0.35 & \pm 0.23 & \pm 0.28 & \pm 0.40 & \pm 0.32 \\
\hline Albumin & 30.28 & 33.44 & 34.82 & 32.69 & 32.80 & 29.07 & 33.15 & 32.56 & 30.62 & 31.35 \\
\hline$\left[\mathrm{g} .1^{-1}\right]$ & \pm 1.09 & \pm 1.79 & \pm 1.03 & \pm 2.00 & \pm 1.48 & \pm 2.33 & \pm 1.30 & \pm 2.41 & \pm 2.04 & \pm 2.02 \\
\hline Glucose & 5.30 & 4.92 & 5.99 & 3.77 & 4.99 & 5.22 & 5.03 & 6.01 & 3.81 & 5.02 \\
\hline$\left[\mathrm{mmol} . \mathrm{l}^{-1}\right]$ & \pm 0.51 & \pm 0.23 & \pm 0.47 & \pm 0.79 & \pm 0.50 & \pm 1.86 & \pm 0.67 & \pm 2.42 & \pm 0.32 & \pm 1.32 \\
\hline Total lipids & 1.68 & 1.62 & 1.84 & 1.83 & 1.74 & 1.76 & 1.59 & 1.80 & 1.64 & 1.70 \\
\hline$\left[\mathrm{g} .1^{-1}\right]$ & \pm 0.08 & \pm 0.49 & \pm 0.25 & \pm 0.20 & \pm 0.26 & \pm 0.87 & \pm 0.39 & \pm 0.49 & \pm 0.21 & \pm 0.49 \\
\hline Cholesterol & 1.85 & 2.28 & 1.93 & 2.18 & 2.06 & 1.75 & 2.06 & 1.97 & 1.99 & 1.94 \\
\hline$\left[\mathrm{mmol} . \mathrm{l}^{-1}\right]$ & \pm 0.35 & \pm 0.38 & \pm 0.22 & \pm 0.21 & \pm 0.29 & \pm 0.24 & \pm 0.25 & \pm 0.12 & \pm 0.04 & \pm 0.16 \\
\hline AST & 0.26 & 0.29 & 0.36 & 0.24 & 0.28 & 0.22 & 0.37 & 0.40 & 0.24 & 0.31 \\
\hline$\left[\mu\right.$ kat. $\left.1^{-1}\right]$ & $\pm 0,02$ & \pm 0.08 & \pm 0.04 & \pm 0.02 & \pm 0.04 & \pm 0.05 & \pm 0.03 & \pm 0.03 & \pm 0.01 & \pm 0.03 \\
\hline $\mathbf{A P}$ & 5.49 & 5.25 & 4.66 & 5.17 & 5.14 & 6.06 & 5.86 & 5.68 & 5.70 & 5.83 \\
\hline$\left[\mu \mathrm{kat} .1^{-1}\right]$ & \pm 0.65 & \pm 0.59 & \pm 1.47 & \pm 0.61 & \pm 0.83 & \pm 0.03 & \pm 0.28 & \pm 0.96 & \pm 0.09 & \pm 0.34 \\
\hline
\end{tabular}


cal parameters in the blood serum in weaning pigs oscillated within relatively wide ranges of physiological values for pigs, presented by the authors Doubek et al. [5] or Kraft and Dürr [15].

The additional part of our study was to investigate the effects of feeding a low crude protein diet to piglets on selected indicators of fermentation processes and nitrogen excretion. The variables of fermentation processes are shown in Table 4.

The evaluation of the fermentation processes through the determination of the VFA in the faeces showed decreasing tendency in individual VFA (acetic, propionic, butyric) and total VFA concentration in the experimental group; however, the differences between the two groups were not significant, except for the concentrations of butyric acid $(\mathrm{P}=0.0017)$. Consistent with the results of the analyses of VFA concentrations, the $\mathrm{pH}$ value of faeces was higher in the experimental group compared to the control group $(\mathrm{P}=0.0180)$.

The differences in dry matter content of the faeces were not statistically significant, although a slightly higher DM content was observed in the experimental group. The levels of ammonia and CP in the faeces of experimental animals were significantly lower $(\mathrm{P}<0.001)$ in comparison with those in the control animals.

\section{DISCUSSION}

The experimental diet with reduced concentration of CP (186.4 g. $\left.\mathrm{kg}^{-1}\right)$ was supplemented with lysine, methionine and threonine according to the NRC recommendations [21] for limiting amino acids. The protein source is a very important factor for the nursery pig's growth, because poor amino acids and protein nutrition have a profound effect on the physiology health status and growth factor of pigs. Diets with high crude protein (CP) content are commonly used for early-weaned pigs. This kind of diet can improve the growth performance of piglets, but is always associated with incidences of diarrhoea $[12,32]$. Indeed, feeding weaned pigs a lower level of crude protein caused lower ammonia concentrations in the small intestine [4] and decreased plasma urea nitrogen, ammonia nitrogen and volatile fatty acids in the ileal digesta [22]. These data are indicative of reduced dietary crude protein levels balanced with AA which has become an alternative approach to reduce the incidence of diarrhoea, in pigs fed antibiotic free diets and still maintain the performance in weaned pigs [11, 24, 33].

Recent studies in pigs have shown that specific dietary amino acids can improve intestinal integrity and function under normal and pathological conditions that protect the

Table 4. Parameters of the fermentation processes in the digestive system

\begin{tabular}{|c|c|c|c|}
\hline Parameter & Control group & Experimental group & $\mathbf{P}^{*}$ \\
\hline $\begin{array}{l}\text { DM } \\
{\left[g . \mathrm{kg}^{-1}\right]}\end{array}$ & $266.1 \pm 12.2$ & $283.0 \pm 23.1$ & 0.1395 \\
\hline $\begin{array}{l}\text { CP } \\
{[\text { g.kg-1 DM] }}\end{array}$ & $244.5 \pm 10.8$ & $203.1 \pm 11.6$ & $<0.001$ \\
\hline $\begin{array}{l}\mathrm{NH}_{3} \\
{\left[\mathrm{mg} \cdot \mathrm{kg}^{-1} \mathrm{DM}\right]}\end{array}$ & $1496 \pm 63.9$ & $1263.8 \pm 35.6$ & $<0.001$ \\
\hline pH & $6.11 \pm 0.33$ & $6.64 \pm 0.32$ & 0.0180 \\
\hline $\begin{array}{l}\text { Acetate } \\
{[\text { g.kg-1] }}\end{array}$ & $23.67 \pm 5.41$ & $21.06 \pm 3.19$ & 0.3327 \\
\hline $\begin{array}{l}\text { Propionate } \\
{\left[\mathrm{g} . \mathrm{kg}^{-1}\right]}\end{array}$ & $14.72 \pm 2.38$ & $12.67 \pm 1.48$ & 0.1034 \\
\hline $\begin{array}{l}\text { Butyrate } \\
{\left[\mathrm{g} . \mathrm{kg}^{-1}\right]}\end{array}$ & $7.68 \pm 0.81$ & $5.94 \pm 0.60$ & 0.0017 \\
\hline $\begin{array}{l}\Sigma \text { VFA } \\
{\left[{\left.\mathrm{g} . \mathrm{kg}^{-1}\right]}^{2}\right.}\end{array}$ & $46.07 \pm 8.59$ & $39.67 \pm 5.33$ & 0.1520 \\
\hline
\end{tabular}

$\mathrm{DM}$ —dry matter; $\mathrm{CP}$ —crude protein; ${ }^{\mathrm{P}}$ —-value and statistical significance VFA-volatile fatty acids 
host from different diseases [18]. Threonine and methionine have been reported to regulate: epithelial cell migration and proliferation, cell differentiation, restoration of epithelial barrier functions, and modulation of cell apoptosis, thereby enhancing mucosal healing after intestinal mucosal inflammation [16]. The optimum proportion of sulphur amino acids and threonine to lysine to maximize the performance of growing pigs has also been reported [34, 35].

Reducing the dietary crude protein level of the diet and supplementing it with limiting crystalline AA can reduce nitrogen excretion, which may prevent surface and ground water contamination $[3,19]$. The increasing availability of synthetic amino acids allows for the reduction of the crude protein level in piglet diets in association with adequate AA supplementation, which maintains sufficient essential AA supply with little or no decrease in growth performance [7].

In our study the reduction of CP $\left(210.8 \mathrm{~g} \cdot \mathrm{kg}^{-1} v s\right.$. $186.4 \mathrm{~g} \cdot \mathrm{kg}^{-1}$ ) only slightly influenced the concentrations of the serum parameters in comparison with the control group, except for the blood urea level. The average total protein concentrations determined in both groups were lower than the reference values reported by Doubek $\left(65-90 \mathrm{~g} . \mathrm{l}^{-1}\right)$ [5], but were consistent with the reference values given by Kraft and Dürr (up to $86 \mathrm{~g}^{-1^{-1}}$ ) [15]. These differences could be due to the very young category of the animals used in our investigations. The concentrations of albumin, glucose, cholesterol, AST and AP in the blood serum in weaning pigs were within the physiological values for pigs $[5,15]$.

Significantly higher levels of blood urea $(\mathrm{P}<0.001)$ in our study were recorded in the control group compared to the experimental group at all weekly intervals. The mean values in the control group, except for the first week, corresponded to the reference values of D oubek et al. (3.6$10.7 \mathrm{mmol}^{-1} \mathrm{l}^{-1}$ [5] or Kraft and Dürr (3.3-8.3 mmol. $\left.\mathrm{l}^{-1}\right)$ [15]. In the experimental group, the mean values of the urea parameter in the monitored intervals were just below the lower reference range. The urea excreted in urine is the main nitrogenous end-product from amino acids catabolism in pigs and plasma or serum urea concentrations may be indicative of excreted nitrogen in urine [27]. The serum or plasma urea nitrogen can be used in various animal species to quantify nitrogen utilization and excretion rates. A lower blood urea nitrogen indicated higher availability of dietary nitrogen and a better use for amino acids with the CP reduction [30].
Shi at al. [29] reported that reducing the dietary CP and providing indispensable crystalline AA can improve AA digestibility and reduce AA excretion. In the study by $\mathrm{Ma}$ et al. [20], the growth performance was not affected in the young pigs weaned at 28 days of age, as the protein level decreased from $20 \%$ to $17 \%$, while the nutrient digestion and absorption or the immune function were improved, which implied that $17 \%$ protein level may be of benefit for nutrients absorption of pigs. This is in agreement with Kumar et al. [14], who concluded that the crude protein concentration can be reduced safely by $10 \%$ to that of requirements in diet without any compromise of performance.

The high dietary CP concentration, as is common in diets for early-weaned pigs, may increase microbial fermentation of undigested protein. The evaluation of the fermentation process through determination of VFA in the faeces performed in our study showed a decreasing tendency in individual VFA in the group with lover level of CP in the diet, but the differences between groups were not significant, except for butyric acid concentration. Htoo et al. [12] detected that the reduction in CP content from 24 to $20 \%$ in weaned pigs leads to decreased faecal ammonia nitrogen $(\mathrm{P}<0.05)$, acetic acid and total VFA concentrations. In the study by $\mathrm{He}$ e et al. [11] feeding low-protein treatments had no effect on the total VFA level for 14 days after weaning. Contrary to our results, pigs in the high protein treatment showed a higher $\mathrm{pH}$ value of faeces on day 10 compared with pigs in the low protein treatments.

\section{CONCLUSIONS}

Our study demonstrated that feeding lower CP content in the diet with the addition of limiting amino acids (lysine, methionine, and threonine) for recommendation of ideal amino acids pattern for piglets after weaning, significantly reduces the blood urea concentration (average concentrations from four weekly collection $2.61 \mathrm{vs} .4 .21 \mathrm{mmol}^{-1}$ ), which leads to an increase in the biological value of the feed mixture. The VFA concentration in the faeces was higher in the control group in our study. The statistically significant differences among the groups were found in the $\mathrm{pH}$ value and butyric acid concentration in the faeces. Also, lower concentrations of ammonia and CP in the faeces of the experimental group was observed $\left(-232.5 \mathrm{mg} \cdot \mathrm{kg}^{-1} \mathrm{DM}\right.$ and $-41.4 \mathrm{~g} . \mathrm{kg}^{-1} \mathrm{DM}$, respectively) compared to the control 
group. The use of synthetic amino acids improved the use of dietary nitrogen, with lower nitrogen excretion into the environment.

\section{REFERENCES}

1. AOAC Association of Official Analytical Chemists International, 2001. In Horwitz, W. (Ed.): Official Methods of Analysis, 17th edn., Arlington, USA. AOAC Inc.

2. Ball, M. E. E., Magowan, E., McCracken, K. J., Beattie, V.E., Bradford, R., Gordon, F. J., et al., 2013: The effect of level of crude protein and available lysine on finishing pig performance, nitrogen balance and nutrient digestibility. AsianAustralasian Journal of Animal Sciences, 26, 4, 564-572. DOI: 10.5713/ajas.2012.12177.

3. Bindas, L., Maskalová, I., 2011: Nutritional possibilities to reduce the nitrogen excretion of pigs. Folia Veterinaria, 55, Supplementum I, 28-30.

4. Bikker, P., Dirkzwager, A., Fledderus, J., Trevisi, P., le Huerou-Luron, I., Lalles, J. P., Awati, A., 2006: The effect of dietary protein and fermentable carbohydrates levels on growth performance and intestinal characteristics in newly weaned piglets. Journal of Animal Science, 84, 12, 3337-3345. DOI: 10.2527/jas.2006-076.

5. Doubek, J., Šlosarková, S., Řeháková, K., Bouda, J., Scheer, P., Piperisová, I., et al., 2010: Interpretation of Basic Biochemistry and Haematology Findings in Animals (In Czech). Noviko a.s., Brno, 102 pp.

6. Duan, Y., Duan, Y., Li, F., Li, Y., Guo, Q., Ji, Y., et al, 2016: Effects of supplementation with branched-chain amino acids to low-protein diets on expression of genes related to lipid metabolism in skeletal muscle of growing pigs. Amino Acids, 48, 9, 2131-2144; DOI: 10.1007/s00726-016-2223-2.

7. Figueroa, J. L., Lewis, P. S., Miller, R.L., Fishcher, R.S., Diedrichsen, R.M., 2002: Nitrogen metabolism and growth performance of gilts fed standard corn-soybean meal diets or low-crude protein, amino acid supplemented diets. Journal of Animal Science, 80, 11, 2911-2919. DOI: 10.2527/2002. 80112911x.

8. Gallo, L., Dalla Bona, M., Carraro, L., Cecchinato, A., Carnier, P., Schiavon, S., 2016: Effect of progressive reduction in crude protein and lysine of heavy pigs diets on some technological properties of green hams destined for PDO drycured ham production. Meat Science, 121, 135-140. DOI: 10. 1016/j.meatsci.2016.06.005.
9. Han, K., Lee, H. J., 2000: The role of synthetic amino acids in monogastric animal production. Review. Asian-Aust. J. Anim. Sci., 1, 4, 543-560. DOI: 10.5713/ajas.2000.543.

10. He, L., Wu, L., Xu, Z., Li, T., Yao, K., Cui, Z., et al., 2016: Low-protein diets affect ileal amino acid digestibility and gene expression of digestive enzymes in growing and finishing pigs. Amino Acids, 48, 1, 21-30. DOI: 10.1007/s00726-015-2059-1.

11. Heo, J.M., Kim, J.C., Hansen, C.F., Mullan, B.P., Hampson, D. J., Pluske, J. R., 2008: Effects of feeding low protein diets to piglets on plasma urea nitrogen, faecal ammonia nitrogen, the incidence of diarrhoea and performance after weaning. Archives of Animal Nutrition, 62, 5, 343-358. DOI: 10.1080/17450390802327811.

12. Htoo, J.K., Araiza, B.A., Sauer, W.C., Rademacher, M., Zhang, Y., Cervantes, M., Zijlstra, R. T., 2007: Effect of dietary protein content on ileal amino acid digestibility, growth performance, and formation of microbial metabolites in ileal and cecal digesta of early-weaned pigs. Journal of Animal Science, 85, 12, 3303-3312. DOI: 10.2527/jas.2007-0105.

13. Kerr, B. J., 2006: Opportunities for utilizing crystalline amino acids in swine. Adv. Pork Prod., 17, 245-254.

14. Kumar, A., Bhar, R., Mandal, A. B., Mendiratta, S. K., 2012: Effect of low protein diets and lysine supplementation on growth performance and carcass characteristics of growing pigs. African Journal of Biotechnology, 11, 57, 12128-12133. DOI: 10.5897/AJB12.1024.

15. Kraft, W., Dürr, M.U., 2001: 30. Reference values. Clinical Laboratory Diagnosis in Veterinary Medicine (Slovak/Czech edition), Hajko \& Hajková, Bratislava, 365 pp.

16. Lan, A., Blachier, F., Benamouzig, R., Beaumont, M., Barrat, C., Coelho, D., et al., 2014: Mucosal healing in inflammatory bowel diseases: is there a place for nutritional supplementation? Inflammatory Bowel Diseases, 21, 1, 198-207. DOI: 10.1097/MIB.0000000000000177.

17. Liao, S.F., Wang, T., Regmi, N., 2015: Lysine nutrition in swine and the related monogastric animals: muscle protein biosynthesis and beyond. SpringerPlus, 4, 1, 147. DOI: 10. 1186/s40064-015-0927-5.

18. Liu, Y., Wang, X., Hou, Y., Yin, Y., Qiu, Y., Wu, G., Hu, C.A.A., 2017: Roles of amino acids in preventing and treating intestinal diseases: recent studies with pig models. Amino Acids, 49, 8, 1277-1291. DOI: 10.1007/s00726-017-2450-1.

19. Lynch, M. B., Sweeney, T., Callan, J. J., Flynn, B., O’Doherty, J. V., 2007: The effect of high and low dietary crude protein and inulin supplementation on nutrient digestibility, nitrogen excretion, intestinal microflora and manure ammonia 
emissions from finisher pigs. Animal, 1, 8, 1112-1121. DOI: 10.1017/S1751731107000407.

20. Ma, X., Tian, Z., Deng, D., Cui, Y., Qiu, Y., 2018: Effect of dietary protein level on the expression of proteins in the gastrointestinal tract of young pigs. J. Agric. Food Chem., 66, 17, 4364-4372. DOI: 10.1021/acs.jafc.7b05655.

21. National Research Council, 2012: Nutrient Requirements of Swine. 11th rev. edn., National Academies Press, Washington, DC, $400 \mathrm{pp}$.

22. Nyachoti, C.M., Omogbenigun, F.O., Rademacher, M., Blank, G., 2006: Performance responses and indicators of gastrointestinal health in early-weaned pigs fed low-protein amino acid-supplemented diets. Journal of Animal Science, 84, 1, 125-134. DOI: 10.2527/2006.841125x.

23. Otto, E. R., Yokoyama, M., Ku, P. K., Ames, N. K., Trottier, N.L., 2003: Nitrogen balance and ileal amino acid digestibility in growing pigs fed diets reduced in protein concentration. Journal of Animal Science, 81, 7, 1743-1753. DOI: $10.2527 / 2003.8171743 x$.

24. Piva, A., Galvano, F., Biagi, G., Casadei, G., 2006: Intestinal fermentation: dietary and microbial interactions. Biology of Growing Animals, 4, 3-31. DOI: 10.1016/S1877-1823 (09)70088-8.

25. Regmi, N., Wang, T., Crenshaw, M. A., Rude, B. J., Liao, S. F., 2018: Effects of dietary lysine levels on the concentrations of selected nutrient metabolites in blood plasma of late-stage finishing pigs. J. Anim. Physiol. Anim. Nutr., 102, 2, 403-409. DOI: $10.1111 /$ jpn.12714.

26. Rezaei, R., Wang, W., Wu, Z., Dai, Z., Wang, J., Wu, G., 2013: Biochemical and physiological bases for utilization of dietary amino acids by young pigs. J. Anim. Sci. Biotechnol., 4, 1, 7. DOI: 10.1186/2049-1891-4-7.

27. Roth, F.X., Raczek, N.N., 2003: Nutritive effectiveness of sorbic acid, effects in piglet feeding. Kraftffutter, 86, $105-110$.

28. Sajeev, E. P. M., Amon, B., Ammon, C., Zollitsch, W., Winiwarter, W., 2018: Evaluating the potential of dietary crude protein manipulation in reducing ammonia emissions from cattle and pig manure: A meta-analysis. Nutrient Cycling in Agroecosystems, 110, 1, 161-175. DOI: 10.1007/s10705017-9893-3.
29. Shi, B., Liu, J., Sun, Z., Li, T., Zhu, W., Tang, Z., 2018: The effects of different dietary crude protein level on faecal crude protein and amino acid flow and digestibility in growing pigs. J. Appl. Anim. Res., 46, 1, 74-80. DOI: 10.1080/ 09712119.2016.1260570.

30. Toledo, J. B., Furlan, A.C., Pozza, P. C., Carraro, J., Moresco, G., Ferreira, S. L., Gallego, A. G., 2014: Reduction of the crude protein content of diets supplemented with essential amino acids for piglets weighing 15 to 30 kilograms. Revista Brasileira de Zootecnia, 43, 6, 301-309. DOI: 10.1590/S151635982014000600004.

31. Toledo, J. B., Furlan, A. C., Pozza, P. C., Piano, L. M., Carvalho, P. L. O., Peñuela-Sierra, L. M., Huepa, L.M.D., 2014: Effect of the reduction of the crude protein content of diets supplemented with essential amino acids on the performance of piglets weighing 6-15 kg. Livestock Science, 168, 94-101. DOI: 10.1016/j.livsci.2014.07.006.

32. Qiao, Y. R., 2003: Low protein diets balanced with amino acids in piglets. Feed Ind., 6, 1-5.

33. Yue, L. Y., Qiao, S. Y., 2008: Effects of low-protein diets supplemented with crystalline amino acids on performance and intestinal development in piglets over the first 2 weeks after weaning. Livestock Science, 115, 2-3, 144-152. DOI: 10. 1016/j.livsci.2007.06.018.

34. Zhang, G. J., Xie, C. Y., Thacker, P. A., Htoo, J. K., Qiao, S. Y., 2013: Estimation of the ideal ratio of standardized ileal digestible threonine to lysine for growing pigs $(22-50 \mathrm{~kg}) \mathrm{fed}$ low crude protein diets supplemented with crystalline amino acids. Animal Feed Science and Technology, 180, 1-4, 83-91. DOI: 10.1016/j.anifeedsci.2013.01.006.

35. Zhang, G. J., Thacker, P. A., Htoo, J. K., Qiao, S. Y., 2015: Optimum proportion of standardized ileal digestible sulfur amino acid to lysine to maximize the performance of $25-50 \mathrm{~kg}$ growing pigs fed reduced crude protein diets fortified with amino acids. Czech Journal of Animal Science, 60, 7, 302-310. DOI: 10.17221/8276-CJAS.

36. Wang, Y., Zhou, J., Wang, G., Cai, S., Zeng, X., Qiao, S., 2018: Advances in low-protein diets for swine. J. Anim. Sci. Biotechnol., 9, 60. DOI: 10.1186/s40104-018-0276-7.

37. Wu, G., 2013: Functional amino acids in nutrition and health. Amino Acids, 45, 407-411. DOI: 10.1007/s00726-013-1500-6.

Received February 15, 2019

Accepted June 10, 2019 